\title{
Model Pemanasan Multi-Tenor pada Battery Percussion Marching Band Institut Seni Indonesia Yogyakarta
}

\author{
Fisabil Mahardika \\ Alumni, Jurusan Musik Fakultas Seni Pertunjukan Institut Seni Indonesia \\ Agus Salim \\ Lektor Kepala pada Jurusan Musik Fakultas Seni Pertunjukan Institut Seni Indonesia
}

\begin{abstract}
The multi tenor is among the instrument sections of a battery percussion ensemble of a marching band. The interesting thing to be studied is that the multi tenor section is supported by more drums than any other sections of battery percussion instruments. Thus, it certainly demands more complex difficulty level than any other instrument sections in battery percussion. There are three formation stages of marching band players (skill, visual, and the like) have to be passed, namely technique, reading, and musicianship. This study focused on the technique as the basic aspects, which is the first of the three stages. This research is based on a case study taken from the practice of an ISI Yogyakarta's student extra-curricular unit, the Saraswati Marching band. Besides the focus, this study also identified the players' obstacles on the learned aspects and how to overcome them in practicing the 15 multi tenors warming up items.
\end{abstract}

Keywords: Multi-tenor; marching band; battery percussion.

\begin{abstract}
Abstrak
Multi tenor adalah salah satu seksi instrumen dari kelompok battery percussion pada sebuah marching band. Hal yang menarik untuk diteliti, multi tenor memiliki drum lebih banyak dibanding instrumen battery percussion lainnya. Dengan demikian tentunya memiliki tingkat kesulitan yang lebih kompleks dibanding instrumen battery percussion lainnya. Tahap pembentukan pemain marching band (skill, visual, dan sebagainya) ada tiga tahap yaitu technique, reading, dan musicianship. Di dalam tiga tahap tersebut, penelitian ini berada pada tahap technique atau hal yang paling dasar. Fokus yang diteliti adalah cara atau model pelatihan warming up multi tenor dengan studi kasus pada Marching band Saraswati ISI Yogyakarta. Selain cara/model melatih, juga diteliti mengenai kendalakendala dan cara mengatasi kendala-kendala dalam melatih 15 warming up multi tenor.
\end{abstract}

Kata Kunci: Multi tenor; marching band; battery percussion.

\section{Pengantar}

Penalaan Marching band merupakan unit musik yang terdiri dari 4 section. Section yang pertama adalah brass section, yang kedua front percussion, ketiga battery percussion, dan terakhir adalah colour guard. Titik lokus yang dibicarakan dalam penelitian ini adalah salah satu dari instrumen yang ada di dalam section battery percussion, yaitu multi tenor.

Penulis memilih instrumen ini karena instrumen ini memiliki drum yang lebih dari satu. Tentunya memiliki tingkat kesulitan yang lebih kompleks dibanding instrumen battery percussion lainnya (snare drum, bass drum, piati/ hand cymbal). Masyarakat perkusi, khususnya yang ada di Jurusan 
Musik Institut Seni Indonesia Yogyakarta, secara formal tidak memperoleh ilmu mengenai instrumen tersebut, sehingga penulis bermaksud untuk membagikan hasil pengamatannya di lapangan tentang multi tenor terhadap teman-teman perkusi/ masyarakat perkusi tersebut. Tentunya juga sebagai referensi bagi para pelatih marching band pada umumnya.

Objek penelitian dalam kasus ini adalah Marching band Saraswati Institut Seni Indonesia Yogyakarta (MBSI YK). Jenis multi tenor yang ada di dalam unit marching band ini adalah quint toms. Quint toms merupakan multi tenor yang memiliki 5 drum. Jenis tenor saat ini ada 6 jenis, yaitu tenor ( 1 drum), duo toms ( 2 drum), tri toms (3 drum), quad toms (4 drum), quint toms (5drum), sextet toms (6 drum).

Karena memiliki drum yang banyak, multi tenor memiliki tingkat kesulitan yang lebih kompleks dibanding instrumen battery percussion lainnya, tetapi meski seperti itu, para pemain multi tenor yang ada di MBSI YK tetap memainkan part-nya secara baik. Baik dalam arti bareng, unison, visual yang sama, style yang sama, karakter yang sama dan sebagainya. Karena merasa sangat penasaran penulis melakukan wawancara kecil terhadap pelatihnya, bahwa bagaimana cara membentuk pemain multi tenor seperti yang dijelaskan di atas.

Andre selaku pelatih section battery percussion 2014/2015 menjawab bahwa kunci dari semua itu adalah pembentukan (skill, visual dan sebagainya) latihan dasar. Yang dilakukan ketika latihan dasar adalah melatih 15 warming up multi tenor. Warming up ini merupakan etude untuk melatih skill/teknik, dan visual (penyeragaman style). Oleh karena itu penulis dalam kasus penelitian ini memperoleh lokus yang lebih khusus untuk di teliti yaitu model pelatihan warming up multi tenor pada ensembel batter percussion studi kasus Marching band Saraswati Institut Seni Indonesia Yogyakarta.

\section{Pembahasan}

\section{Pemilihan Pemain}

Pemilihan pemain di dalam marching band, tentunya tidak sekedar memilih. Termasuk khususnya pemilihan pemain pada instrumen multi tenor. (Caneva, 1994: 118119)

a. Pilih pemain yang memiliki tubuh yang lebih kuat dibanding pemain battery percussion lainnya.

b. Pilih pemain yang memiliki teknik split yang baik. Rudiment juga harus baik tetapi titik beratnya teknik split yang baik. Jika ada pemain yang memiliki rudiment yang baik sekali sebaiknya ditempatkan pada pemain snare drum.

Dari penjelasan di atas dapat disimpulkan bahwa teknik split pada permainan instrumen multi tenor itu sangat penting. Sehingga teknik ini harus dilatih sangat sering.

\section{Zona Pukul Instrumen Multi Tenor}

Berikut adalah contoh Ilustrasi zona pukul instrumen multi tenor:
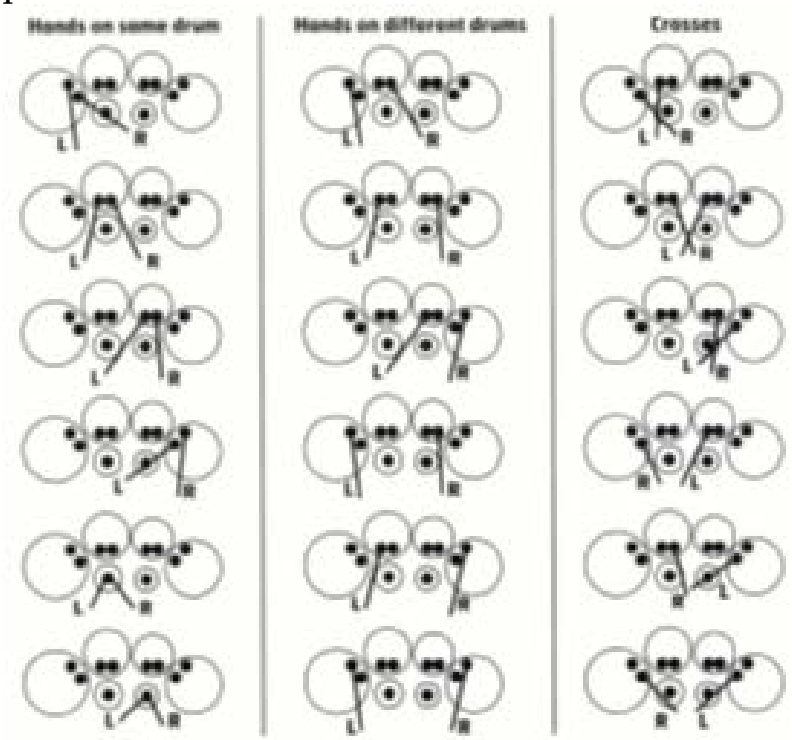

Ilustrasi 1

Zona pukul Multi Tenor

(Casella, dkk, 2007, Ibid.)

Zona pukul instrumen multi tenor dibagi menjadi tiga, yaitu Hands on same 
drum, Hands on different drums, dan Crosses. (Casella, dkk, 2007: 118-119)

Hands on same drum merupakan zona pukul pada satu drum. Hands on different drum merupakan zona pukul pada drum yang berbeda (lebih dari satu drum). Crosses merupakan zona pukul ketika posisi menyilang.

\section{Empat Teknik Pukulan Perkusi}

Dalam permainan perkusi dikenal adanya empat macam pukulan sebagai berikut:

a. Full Stroke. Pukulan ini adalah pukulan yang mana berawal dari posisi up dan berakhir pada posisi up. Atau start up, finish up/ high to high.

b. Down Stroke. Pukulan ini adalah pukulan yang mana berawal dari posisi up dan berakhir pada posisi down. Atau start up, finish down/ high to low.

c. Up Stroke. Pukulan ini adalah pukulan yang mana berawal dari posisi down dan berakhir pada posisi up. Atau start down, finish up/low to high

d. Tap Stroke. Pukulan ini adalah pukulan yang mana berawal

\section{Pemanasan Marching band Saraswati Institut Seni Indonesia Yogyakarta}

Berikut ini dipaparkan 15 model latihan yang menjadi bahan penelitian ini. Beberapa ekstrak contoh notasi pada paparan ini diambil dari dokumen warming up multi tenor Marching band Saraswati Institut Seni Inonesia Yogyakarta 2014/2015, dan juga merupakan hasil transkripsi langsung oleh penulis.

\section{a. Warming up Nomor 1}

Warming up ini melatih teknik dasar single stroke satu tangan. Biasanya pemanasan ini diberi nama 8-8-16, yaitu 8 kali pukulan tangan kanan, 8 kali pukulan tangan kiri, dan 16 kali pukulan tangan kanan, lalu dibalik dimulai dari tangan kiri, lalu ditutup satu pukulan tangan kanan.

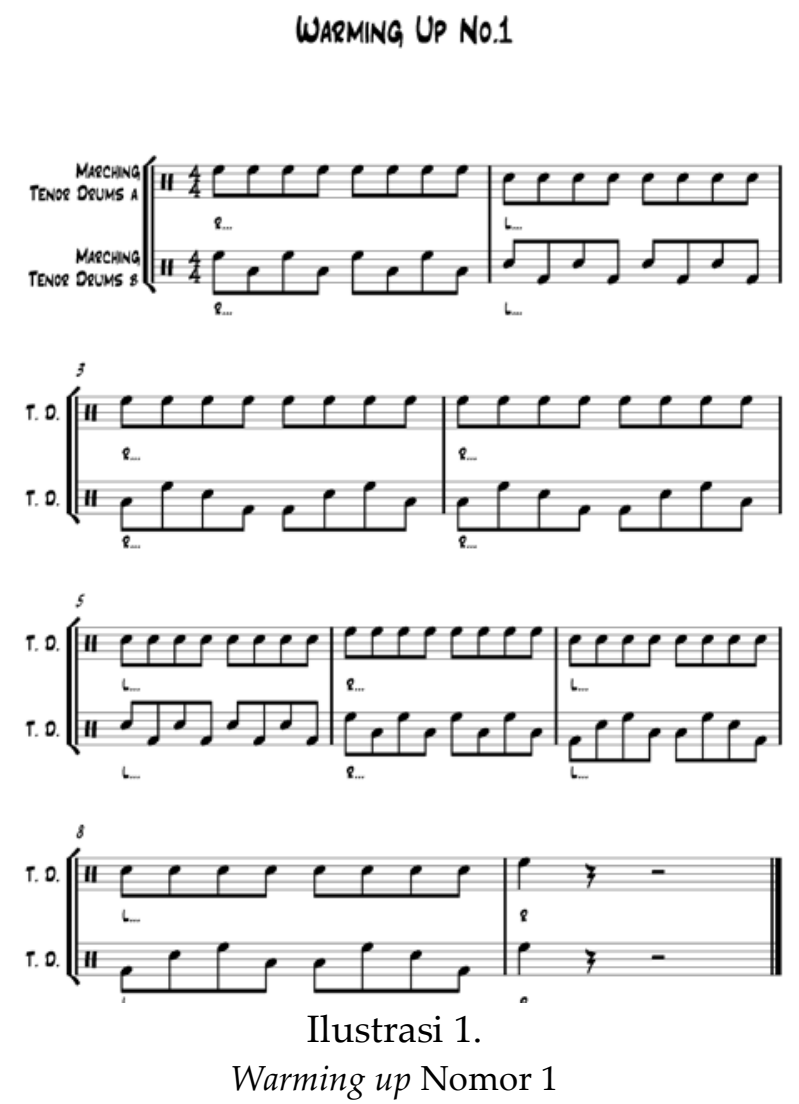

Titik berat pemanasan ini adalah teknik legato. Untuk memperoleh teknik legato maka harus menggunakan teknik pukulan full stroke. Pada pemanasan nomor $1 \mathrm{~b}$ merupakan dasar teknik split (perpindahan dari drum satu ke drum lainnya), maka hal ini sangat penting untuk dikuasai. Seperti cara split harus membentuk garis $\mathrm{U}$ bukan $\mathrm{V}$. Berikut adalah notasi warming up nomor 1 .

Kendalanya biasanya ketika split, pemain menggunakan lengan. Maka solusinya pelatih menjelaskan mana yang harus dikunci sebagai poros kekanan dan kekiri yaitu tangan bagian siku. Lalu, perggelangan adalah poros ke atas dan ke bawah.

\section{b. Warming up Nomor 2.}

Pemanasan ini adalah untuk melatih teknik aksen tap. Ketika ada notasi beraksen maka dinamiknya forte dengan teknik down stroke, dan notasi yang tidak memiliki aksen, 
memiliki dinamik piano dengan teknik pukulan tap stroke. Maka otomatis ketika melakukan split aksen tap, akan menimbulkan gerakan bergaris L. Berikut Ilustrasi notasi pemanasan ini.
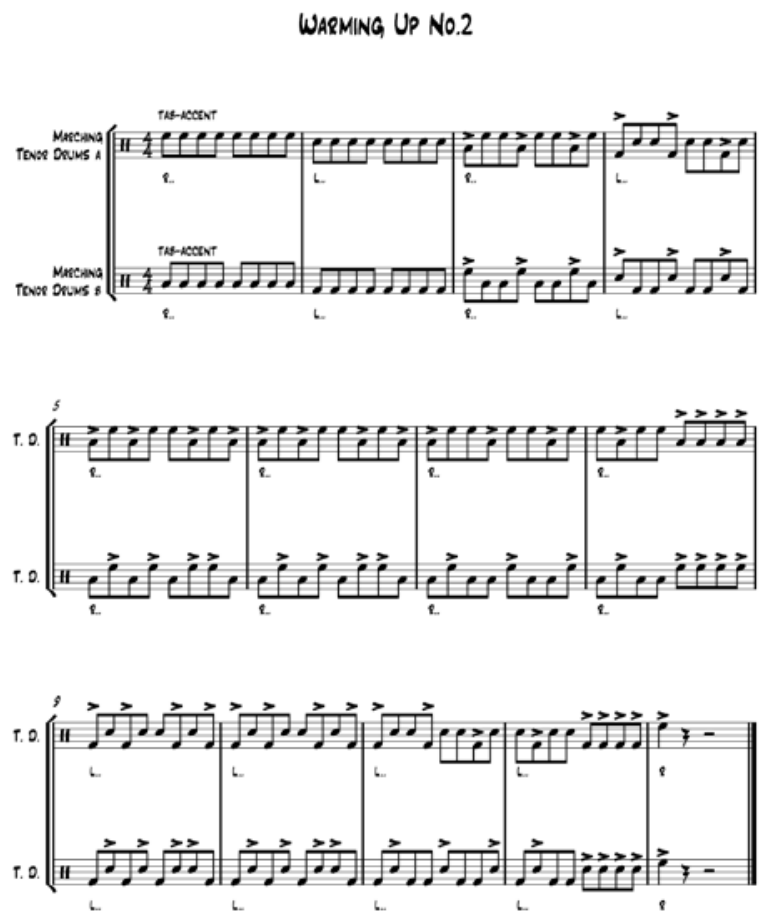

Ilustrasi 2.

Warming up Nomor 2

Kendala pemanasan ini biasanya para pemain multi tenor kesulitan melakukan teknik down stroke yang benar-benar mati atau berhenti di bawah. Sehingga menimbulkan 3 dinamik yaitu forte, mezzo piano dan piano. Seharusnya hanya 2 dinamik saja yaitu forte dan piano saja. Solusinya adalah dilatih dengan tempo yang pelan dan benar-benar memperhatikan teknik down stroke yang benar-benar mati atau berhenti di bawah sebagai persiapan melakukan pukulan tap stroke. Ketika split tetap diingatingat tentang gerakan bergaris $\mathrm{L}$.

\section{c. Warming up Nomor 3.}

Pemanasan ini melatih rudiment single stroke dua tangan. Diawali dari notasi 1/8 dan dilanjutkan dengan notasi 1/16. Hal ini merupakan salah satu dari stick control.
Semua dilakukan dengan cara legato. Pemanasan nomor satu merupakan dasar untuk pemanasan ini. Berikut notasi warming up nomor 3.

Marchng TENor Dorus WARMING UP N0.3

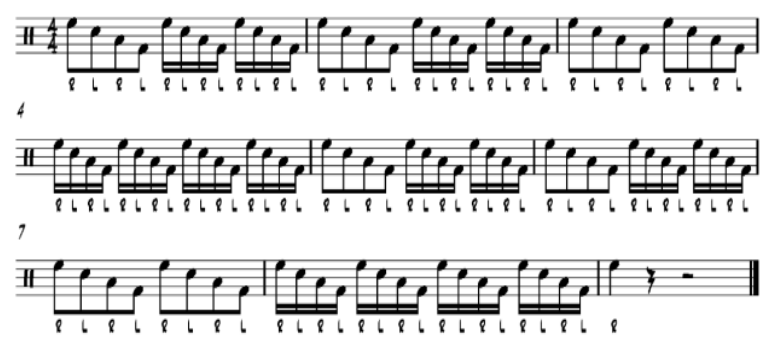

Ilustrasi 3.

Warming up Nomor 3

Kendala pemanasan ini biasanya pemain multi tenor kesulitan untuk legato ketika notasi 1/8. Maka solusinya, pelatih selalu mensugesti para pemain multi tenor untuk selalu mengalir dan memakai teknik full stroke bukan down stroke, serta tetap fokus untuk membentuk garis U untuk teknik split.

\section{d. Warming up Nomor 4.}

Pemanasan keempat ini merupakan pemanasan untuk melatih teknik didle satu tangan tanpa aksen. Pada birama 5 terakhir disisipi triple. Dipercaya bahwa jika triple bisa dilakukan dengan baik maka didle akan jauh lebih baik cara melakukannya.

Jika dilihat notasi 4 berikut ini, pemanasan memiliki 4 pola yaitu pola a,b,c, dan $d$. Kendalanya biasanya para pemain multi tenor terbalik-balik polanya. Hal ini biasanya para pemain kurang menghafal. Maka solusinya, bagi pemain yang kurang hafal, dipisah dari line untuk menghafal sendiri hingga hafal. Hal ini juga sebagai konsekuensi karena tidak menghafal ketika di rumah masing-masing sebelum latihan. Berikut adalah notasi pemanasan ini. 


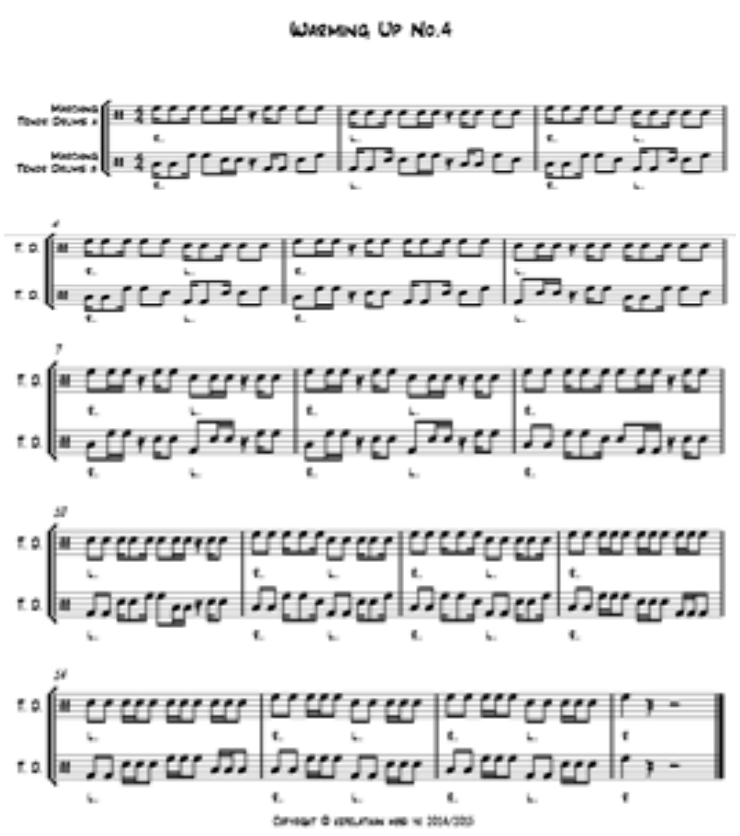

Ilustrasi 4.

Warming up Nomor 4

\section{e. Warming up Nomor 5.}

Pemanasan kelima ini merupakan pemanasan atau etude untuk melatih teknik double strokelopen roll dua tangan. Pemanasan diawali dari pola priksa/pola dasar notasi $1 / 8$ kemudian melakukan double stroke pada masing-masing tangan.

Kendalanya melakukan dinamik bergerak, seperti misalnya cressendo (lihat Notasi 6) tempo selalu naik dan sebaliknya, maka solusinya adalah ketika memainkan pemanasan ini harus memakai metronome.

Untuk meningkatkan akurasi hasil yang maksimal Metronome sangat bagus digunakan untuk semua pemanasan. Bahkan ketika penggarapan lagu, diwajibkan memakai metronome oleh pelatihnya.

Berikut adalah latihan kelima:
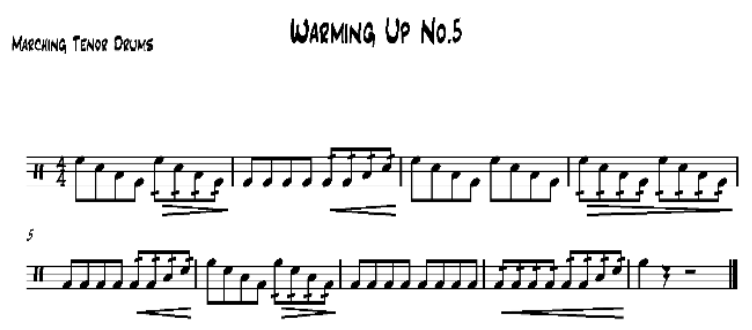

Ilustrasi 5.

Warming up Nomor 5

\section{f. Warming up Nomor 6 .}

Pemanasan ini merupakan etude untuk melatih teknik single accent tap stroke. Pemanasan ini melatih keseimbangan tangan kanan dan tangan kiri sebagai pemimpin pukulan. Hal tersebut terlihat pada aksenaksen tersebut. Berikut adalah Ilustrasi notasinya.

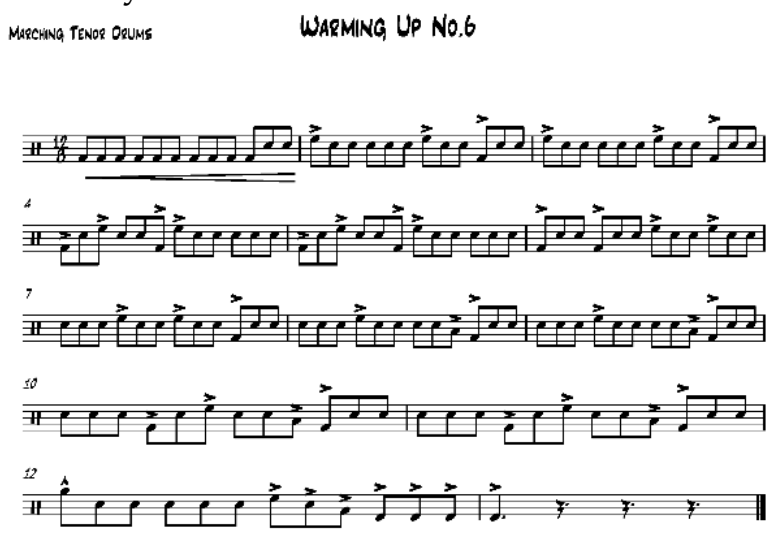

Ilustrasi 6.

Warming up Nomor 6

Kendalanya adalah biasanya para pemain sering keliru memukul drum atau salah pukul drum. Solusinya biasanya pelatih memisah pemain yang salah pukul tersebut untuk keluar diluar line untuk menghafal. Hal ini merupakan salah satu dari konsekuensi jika kurang hafal. Di dalam pelatihan ini juga disisipkan doktrinasi dengan tujuan bertanggung jawab atau disiplin materi. Konsekuensi yang dijelaskan di atas merupakan salah satu dari doktrinasi disiplin materi. Hal ini merupakan salah satu pemahaman non teknis yang disisipi kedalam latihan dasar.

\section{g. Warming up Nomor 7.}

Pemanasan ini merupakan etude untuk melatih teknik paradidle, double paradidle, dan triple paradidle. Pemanasan ini memiliki 2 pola yaitu $7 \mathrm{a}$ dan $7 \mathrm{~b}$. Masingmasing memiliki split yang berbeda. Yang paling menarik adalah pola $7 \mathrm{~b}$. Pola $7 \mathrm{~b}$ terdapat pemanasan untuk melatih teknik split didle keluar. Biasanya pelatih membagi pa-ra-di-dle berarti R-L-R-R atau L-R-L-L. 
Pada setiap pa itu selalu diberi aksen. Berikut adalah Ilustrasi notasinya.

\section{WARMING UP N0.7}
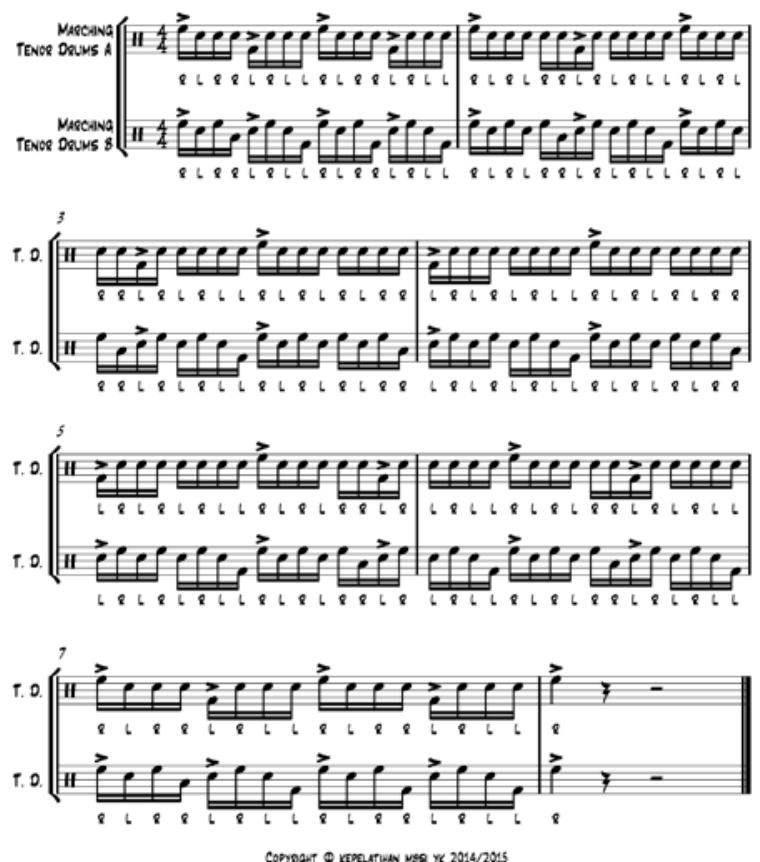

Ilustrasi 7.

Warming up Nomor 7

Kendalanya adalah biasanya para pemain multi tenor kesulitan melakukan teknik split didle keluar. Split ini terletak ketika setiap memainkan didle. Maka solusinya adalah notasi di bawah ini.

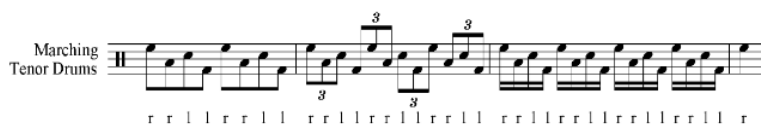

Ilustrasi 8.

Split didle keluar

(Transkripsi oleh penulis)

Notasi di atas merupakan cara pelatih mengatasi kendala tersebut. Pelatih tidak memberi part solusi, tetapi langsung diajarkan di lapangan. Partitur solusi tersebut adalah berdasarkan pengamatan penulis yang ditulis oleh penulis agar lebih jelas untuk disampaikan. h. Warming up Nomor 8 .

Pemanasan ini merupakan etude yang mempelajari teknik open roll satu tangan yang beraksen. Di dalam pemanasan ini juga mempelajari teknik dasar split didle keluar maupun kedalam. Berikut notasinya.

\section{WARMING UP N0.8}

MARCHING TENOR DRUMS
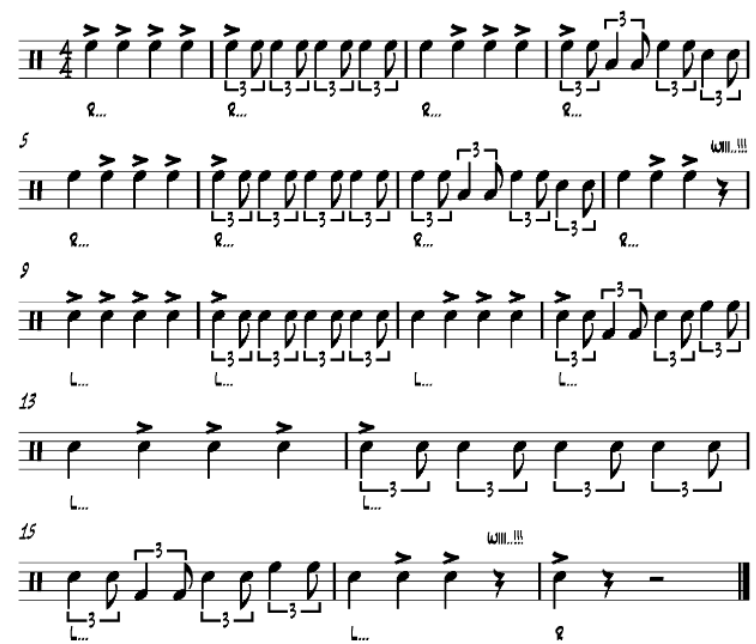

Ilustrasi 9.

Warming up Nomor 8

Kendalanya adalah kesulitan pada teknik split didle kedalam, karena belum dipelajari, sedangkan split didle keluar sudah di pelajari di pemanasan sebelumnya. Solusimya sebagai berikut.

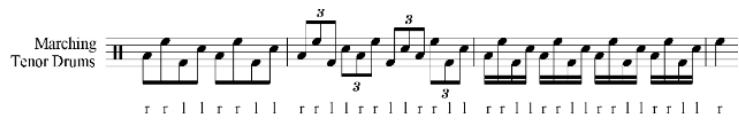

Ilustrasi 10

Solusi split didle ke dalam

Notasi solusi di atas diperoleh dari pengamatan penulis di lapangan yang ditulis ulang berdasarkan pelatih meng-ajarkan langsung praktek di lapangan. Pelatih hanya mengulang-ulangi notasi tersebut per biramanya yang diperlukan saja. 


\section{i. Warming up Nomor 9.}

Pemanasan ini merupakan etude untuk melatih triplet roll atau notasi triplet yang memiliki roll atau open roll. Pada birama 4 terakhir dan 3 terakhir terdapat notasi beraksen dan ada roll, maka bagian tersebut merupakan aplikasi dari warming up nomor 8. Berikut adalah notasi pemanasan ini.

WARMING UP N0.9
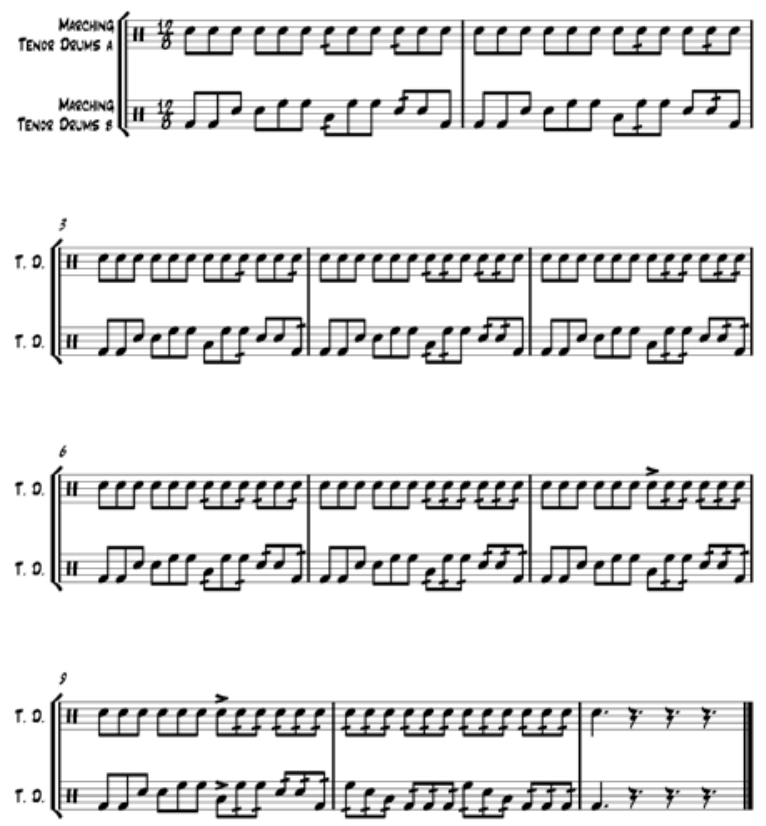

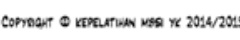

Ilustrasi 11.

Warming up Nomor 9

Kendala pada pemanasan ini biasanya pemain multi tenor terbalik-balik roll-nya ketika memainkan pola $9 \mathrm{~b}$ atau split. Hal ini karena belum hafal saja. Solusinya instruktur selalu mengulang-ulang birama yang salah dan dibetulkan. Sehingga pemain tahu mana yang salah mana yang betul dan semakin hafal.

\section{j. Warming up Nomor 10.}

Pemanasan ini merupakan etude untuk melatih teknik open roll pada notasi seperenambelasan. Pemanasan ini terdapat aksen. Pemanasan ini adalah variasi pemanasan untuk melatih open roll beraksen. Berikut notasi pemanasan ini.
WARMING UP No.10
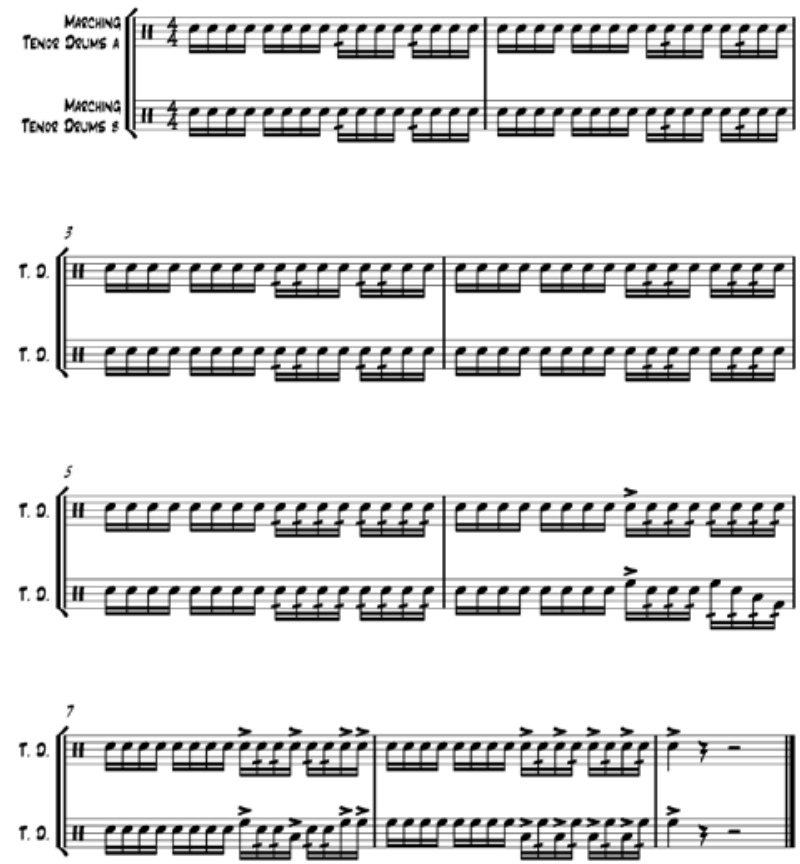

comber o romunuw wsa y 2014/2015

Ilustrasi 12.

Warming up Nomor 10

Kendala pemanasan ini adalah terletak pada birama 8. Seharusnya pukulan pertama pada birama 8 adalah tap stroke (karena tidak terdapat aksen), tetapi biasanya pemain memukul aksen/sedikit aksen. Hal ini karena terbawa pada pukulan sebelumnya terdapat aksen. Maka solusinya, pelatih memastikan bahwa ke-tika aksen pada notasi di birama sebelum 8 , harus memakai teknik pukulan down stroke sebagai persiapan akan memukul tap stroke.

\section{k. Warming up Nomor 11.}

Pemanasan ini adalah variasi open roll beraksen pada notasi triplet. Pemanasan dengan cara ini berfungsi untuk melatih kedudukan tangan kanan sebagai pemimpin. Jika dibalik maka tangan kiri juga dapat berfungsi sebagai pemimpin. Hal ini terlihat pada aksen tersebut. Berikut ini adalah ilustrasi untuk open roll beraksen pada notasi triplet. 


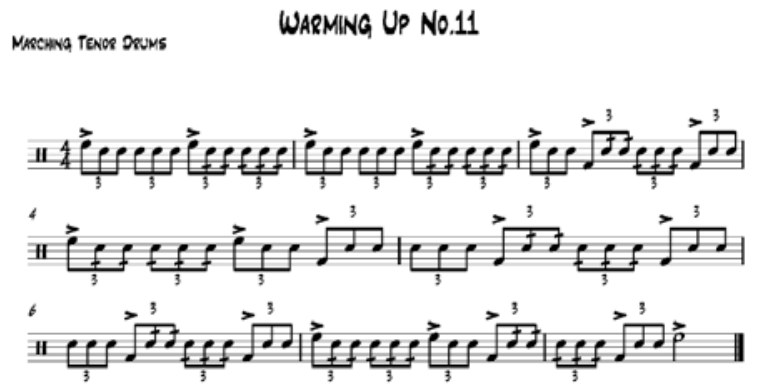

Ilustrasi 13.

Warming up Nomor 11

Kendalanya adalah setelah transisi aksen yang dipimpin dari tangan kanan ke kiri atau sebaliknya, maka roll menjadi melebar. Maka solusinya, selalu mendengarkan akurasi ritmik patokan teman yang paling tengah atau teman yang paling dekat dengan snare drum (jika 2 pemain). Pemain multi tenor yang dekat dengan snare drum, harus menyamakan akurasi ritmik snare drum.

\section{Warming up Nomor 12.}

Pemanasan ini melatih open roll dari notasi seperenambelasan ke notasi triplet dan sebaliknya. Kendalanya adalah ketika melakukan open roll pada notasi triplet, terlalu rapat karena terbawa notasi roll pada notasi seperenambelasan dan sebaliknya menjadi melebar. Maka solusinya pelatih hanya menunjukan open roll mana yang kurang lebar dan yang kurang rapat. Berikut notasinya:

MARCHING TENOR DQUMS

WARMING UP NO.12

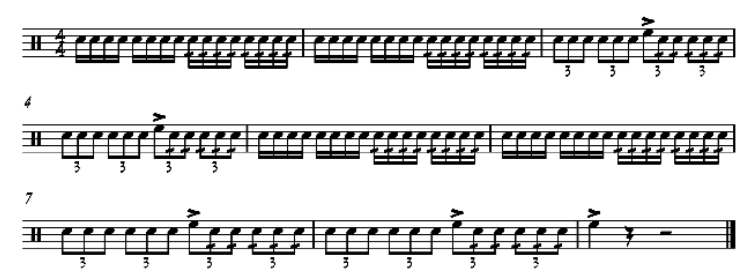

Ilustrasi 14.

Warming up Nomor 12

\section{m. Warming up Nomor 13.}

Pemanasan ini melatih variasi open roll. Tetapi titik tekan dari pemanasan ini adalah untuk melatih teknik hurta pada birama kedua. Notasi ini merupakan hybrid rudiment karena ada dua unsur yaitu tangan kanan melakukan didle dan tangan kiri melakukan single stroke satu tangan. Semua dimainkan secara legato. Berikut notasinya.

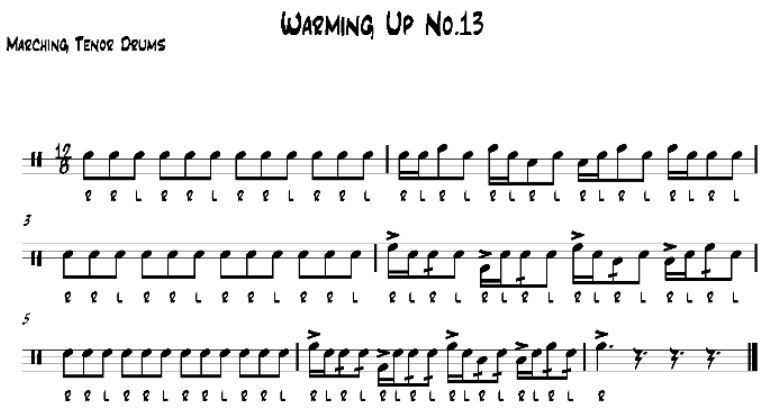

Ilustrasi 15.

Warmig Up Nomor 13

Kendalanya pada notasi hurta, adalah tidak legato. Hal tersebut karena tangan kiri kurang full stroke, berhenti-henti/ tidak legato, atau malah salah teknik yaitu down stroke. Solusinya pelatih hanya membetulkan dengan sugesti untuk terus mengalir dan legato, atau mencontohkannya. Tentunya akan membutuhkan waktu untuk sebuah pencapaian yang sempurna. Yang penting waktu tersebut adalah waktu yang efektif.

\section{n. Warming up Nomor 14.}

Pemanasan ini adalah pemanasan untuk melatih teknik open roll dari notasi seperlapan ke notasi triplet dan sebaliknya. Berikut notasinya.

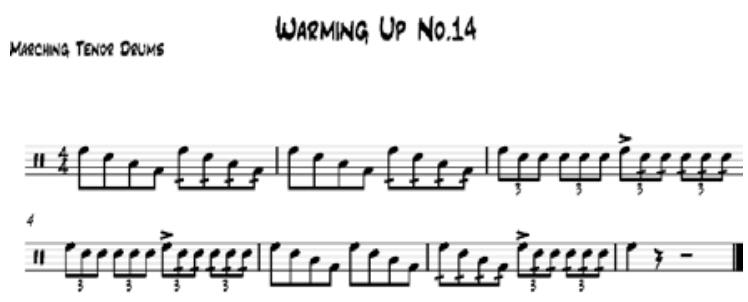

Ilustrasi 16.

Warming up Nomor 14

Kendala pemanasan ini sama dengan warming up nomor 12, yaitu teknik open roll yang kurang rapat dan kurang lebar. Maka solusinya sama saja yaitu pelatih hanya 
menunjukkan notasi open roll mana yang kurang lebar atau rapat atau mencontohkannya.

\section{o. Warming up Nomor 15.}

Pemanasan ini melatih teknik flam. Berikut notasinya.

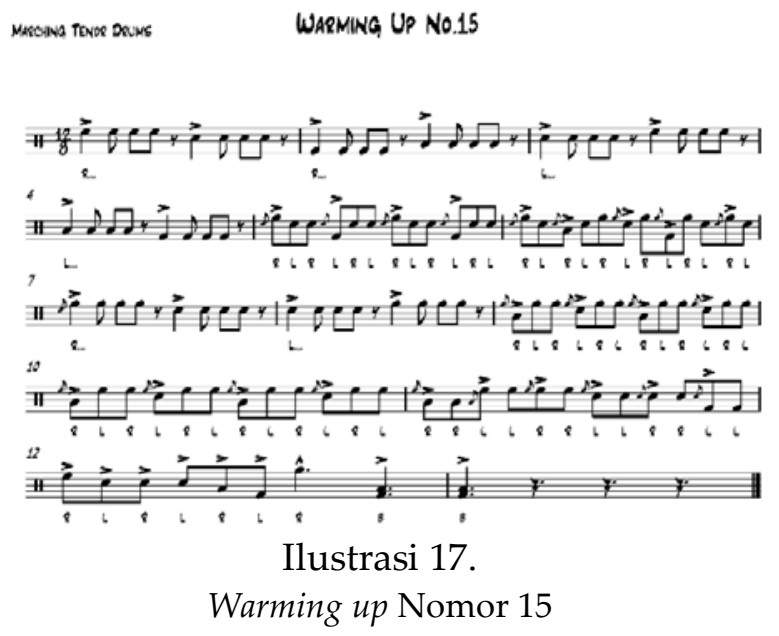

Lihat pada birama 1-4 dan 7-8. Pola ritmik tersebut muncul dari pola triplet flam yang mana flam terdapat pada setiap beat pertama, jika dipecah satu tangan saja, maka pola ritmiknya menjadi seperti pada birama 1-4 dan 7-8. Kendala pemanasan ini adalah ketika split (perpindahan drum satu ke drum lainnya), flam selalu melebar, maka solusinya semua notasi dimainkan pada satu drum saja hingga akurasi ritmik benar dan dipastikan lagi hingga benar-benar tidak kebetulan kebenarannya, lalu melakukan split.

\section{Kendala-Kendalanya dan Solusi.}

Biasanya pada awal dilatih semua pemanasan di atas, para pemain multi tenor tidak bareng melakukannya. Solusinya adalah jika ada 3 atau lebih pemain multi tenor maka mendengarkan yang paling center/patokan tengah yang ditunjuk pelatihnya. Jika ada 2 pemain, maka mendangarkan pemain multi tenor yang paling dekat dengan snare drum. Oleh karena itu pilih pemainmulti tenor yang memiliki kemampuan yang sangat baik untuk dijadikan patokan tersebut.

\section{Penutup}

Tahap pelatihan marching band ada tiga yaitu technique, reading dan musicianship. Semua yang di bahas di atas yaitu 15 warming up multi tenor, merupakan tahap paling dasar yaitu technique. Penyeragaman teknik tersebut juga memengaruhi visualisasi. Cara melakukan yang sama maka biasanya memiliki visual yang sama. Yang dimaksud dari visual ini adalah seperti ketinggian stick yang sama, gerakan/style yang sama dan sebagainya.

Warming up nomor satu hingga tujuh tersebut merupakan hal yang paling dasar. Didalam warming up nomor 1-7 terdapat teknik single stroke, double stroke, dan paradidle. Ketiga teknik tersebut merupakan hal yang dasar.

Pemanasan berikutnya (nomor 8-14) adalah variasi-variasi dari double stroke atau open roll yang mana terdapat notasi beraksen. Kecuali warming up nomor 13 merupakan pemanasan yang titik tekannya untuk melatih teknik hurta yang merupakan hybrid rudiment. Disebut hybrid rudiment karena memiliki dua unsur yaitu pada tangan kanan memainkan didle dan tangan kiri memainkan single stroke satu tangan.

Terakhir, warming up nomor 15 adalah pemanasan untuk melatih teknik flam. Kelima belas pemanasan di atas merupakan pola-pola yang sering muncul di dalam repertoar marching band, sehingga 15 warming up di atas sangat penting dipelajari sampai sempurna, agar pemain multi tenor dapat memainkan repertoar-repertoar marching band secara baik.

\section{Referensi}

Caneva, Thomas. 1994. The Complete Marching band Resource Manual. Philadelphia: University of Penn-sylvania Press. 
16 ] Fisabil Mahardika \& Agus Salim: Model Pelatihan Pemanasan Multi-Tenor pada Battery Percussion

Savage, Matt. 2001. Savage Rudimental Workshop: A Musical Approach to Develop Total Control of the 40 P.A.S. Rudiments. USA: Alfred Publishing CO. 